We are grateful to Diane Coulson, Heather Forshaw, Christine Kinsella, and Pamela McCrorie for the diligent way they did the case note abstraction; to Julian Smith for constructing and managing the database and for programming the portable computers used to collect this information; and to Susan Fritz for collecting information on policy with regard to vitamin $\mathrm{K}$ prophylaxis across the region and for locating the whereabouts of many of the obstetric and neonatal case notes. We are grateful to the staff of all the hospital medical records departments for facilitating access to records and to clinical colleagues, active and retired, for information on vitamin K policy. We thank Drs Olsen and Roman and Professors Golding and von Kries for providing data, and those responsible for the current national case-control study of childhood cancer for access to their data abstraction form, from which the form used in this study was developed. Copies of the full study report, as submitted to the Department of Health in May 1996, are available from the corresponding author in request.

Contributors: AWC initiated the study and coordinated the design of the project, discussed the analysis strategy and the interpretation of the results, and participated in writing the manuscript. ENH was involved in the discussion, developing the design of the project, and analysing and interpreting the results and took the lead role in writing the manuscript. MC performed the statistical analysis and participated in discussions on interpreting results. Julian Smith designed the database and downloaded data. LP designed the study and data abstraction procedure, supervised data collection, checked the data download before statistical analysis, discussed the interpretation of results, and participated in writing the manuscript. Diane Coulson, Heather Forshaw, Christine Kinsella, and Pamela McCrorie performed all the case note abstraction. LP, ENH, and AWC are guarantors for the study.

Funding: This study was funded by the Department of Health. Supplementary support for MC, LP, and JS came from the North of England Children's Cancer Research Fund, and for Lorna More, the secretary of the children's cancer registry, from the Royal Victoria Infirmary NHS Trust.

Conflict of interest: None.

Klebanoff MA, Read JS, Mills JL, Shiono PH. The risk of childhood cancer after neonatal exposure to vitamin K. N Engl J Med 1993;329:905-8.

2 Ekelund H, Finnström O, Gunnarskog J, Källén B, Larsson Y. Administration of vitamin $\mathrm{K}$ to newborn infants and childhood cancer. BMJ 1993;307:89-91.

Olsen JH, Hetz H, Blinkenberg K, Verder H. Vitamin K regimens and incidence of childhood cancer in Denmark. BMJ 1994;308:895-6.

4 Von Kries R, Göbel U, Hachmeister A, Kaletsch U, Michaelis J. Vitamin K and childhood cancer: a population based case-control study in Lower and childhood cancer: a population based

5 Ansell P, Bull D, Roman E. Childhood leukaemia and intramuscular vitamin K: findings from a case-control study. BMJ 1996;313:204-5.
6 Zipursky A. Vitamin K at birth [editorial]. BMJ 1996;313:179-80.

7 Golding J, Paterson M, Kinlen LJ. Factors associated with childhood cancer in a national cohort study. Br J Cancer 1990;62:304-8.

8 Golding J, Greenwood R, Birmingham K, Mott M. Childhood cancer, intramuscular vitamin $\mathrm{K}$, and pethidine given during labour. $B M J$ 1992;305:241-6.

9 Draper G. The geographical epidemiology of childhood leukaemia and non-Hodgkin lymphomas in Great Britain 1966-83. London: HMSO 1991.

10 Craft AW, Ammenidine HA, Scott JES, Wagget J. The Northern Region Children's Malignant Disease Registry 1968-82. Incidence and survival. Br J Cancer 1987;56:853-8.

11 Breslow NE, Day NE. Statistical methods in cancer research. Vol I. The analysis of case-control studies. Lyons: IARC Scientific Publications, 1980:248-79. (Publication No 32.)

12 Breslow NE, Day NE. Statistical methods in cancer research. Vol II. The design and analysis of cohort studies Lyons: IARC Scientific Publications, 1987: 135-7. (Publication No 82.)

13 Greaves MF. Aetiology of acute leukaemia. Lancet 1997;349:344-9.

14 Draper G. Cancer. In: Botting B, ed. The health of our children. OPCS decennial supplement. London: HMSO, 1995:140. (OPCS series DS No 11.)

15 McNinch AW, Upton C, Samuels M, Shearer MJ, McCarthy P, Tripp JH, et al. Plasma concentrations after oral or intramuscular vitamin $\mathrm{K} 1$ in neonates. Arch Dis Child 1985;60:814-8.

16 Von Kries R, Hachmeister A, Göbel U. Repeated oral vitamin K prophylaxis in West Germany: acceptance and efficacy. BMJ 1995;310:1097-8.

17 Cornelissen M, von Kries R, Loughnan P, Schubiger G. Prevention of vitamin $\mathrm{K}$ deficiency bleeding: efficacy of different multiple oral dose schedules of vitamin K. Eur J Pediatr 1997;156:126-30.

18 Hansen KN, Ebbesen F. Neonatal vitamin K prophylaxis in Denmark: three years' experience with oral administration during the first three months of life compared with one oral administration at birth. Acta Paediatr 1996;85:1137-9.

19 Cornelissen M, Hirasing R. Vitamin K for neonates. BMJ 1994;309: 1441-2.

20 McNinch A. Vitamin K deficiency bleeding. London: Surveillance Unit of the Royal College of Paediatrics and Child Health, 1996

21 Schubiger G, Tönz O, Grüter J, Shearer MJ. Vitamin K1 concentration in breast-fed neonates after oral or intramuscular administration of a single dose of a new mixed-micellar preparation of phylloquinone. J Pediatr Gastroenterol Nutr 1993;16:435-9.

22 Baenziger O, Braegger CP, Fanconi S. Oral vitamin K prophylaxis for newborn infants: safe enough? Lancet 1996;348:1456.

23 Laughnan PM, McDougall PN. Does intramuscular vitamin K1 act as an unintended depot preparation ? J Paediatr Child Health 1996;32:251-4.

24 Greer FR, Marshall SP, Foley AL, Suttie JW. Improving the vitamin K status of breastfeeding infants with maternal vitamin $\mathrm{K}$ supplements. Pediatrics 1997;99:8-92.

25 Nishiguchi T, Saga K, Sumimoto K, Okada K, Terao T. Vitamin K prophylaxis to prevent neonatal vitamin $\mathrm{K}$ deficient intracranial haemorrhage in Shizuoka prefecture. Br J Obstet Gynaecol 1996;103:1078-84.

26 Department of Health and Social Services. Reports on health and social subjects. No 32. Present day practice in infant feeding: third report. London: HMSO, 1988:35-6.

27 Roman E, Ansell P, Bull D. Leukaemia and non-Hodgkin's lymphoma in children and young adults: are prenatal and neonatal factors important determinants of disease? Br J Cancer 1997;76:406-15.

(Accepted 17 November 1997)

\title{
Racial discrimination in the allocation of distinction awards? Analysis of list of award holders by type of award, specialty and region
}

\author{
Aneez Esmail, Sam Everington, Helen Doyle
}

There has been much concern about the possibility of discrimination in the allocation of distinction awards to consultants. The aim of this study was to assess whether there is any disparity between white and non-white consultants in the receipt of distinction awards.

\section{Methods and results}

We used the list of all consultants in England and Wales who are currently in receipt of a distinction award published by the Advisory Committee on Distinction
Awards $^{1}$ to determine the ethnicity of award holders using the surname of the award holder as a proxy for ethnicity. We classified consultants with Asian, Chinese, and African names as non-white and consultants with Anglo-Saxon, East European, and South European names as white. All consultants are eligible for distinction awards, so for denominator data we obtained the number of consultants by region and specialty from the 1996 census of the NHS workforce carried out by the Department of Health. ${ }^{2}$ This census categorises consultants as white, black, Asian, other ethnic, and not known. We classified black, Asian, and other ethnic as
See editorial by Rubin Harvard Medical School, Boston, MA 02115-5818, USA Aneez Esmail visiting professor of social medicine continued over BMJ 1998;316:193-5 
Medical

Practitioners Union,

London SE1 1UN

Sam Everington

vice president

Department of

General Practice,

University of

Manchester,

Rusholme Health

Centre, Manchester

M14 5NP

Helen Doyle

research assistant

Correspondence to:

Dr Esmail

aesmail@warren.

med.harvard.edu non-white. We excluded the not known category in our calculations.

We tabulated results of award holders by type of award, specialty (only those with more than 50 award holders), and NHS region. The ratios of the proportion of white and non-white consultants with awards were calculated together with their confidence intervals (see table).

\section{Comment}

Distinction awards are "granted to individuals solely on the grounds of merit. Consultants from all backgrounds, regardless of gender and race, are judged equally." The systematic differences that we have tabulated between white and non-white consultants therefore need some explanation.

The use of surnames as a proxy for ethnicity is open to criticism because of the problems of misclassification. This method cannot identify people with European sounding names who may be Asian or AfroCaribbean and who would therefore have been classified as white. Nevertheless, this misclassification would probably not have altered the very large differences that we observed. We did not have ethnicity information on $12 \%$ of the consultants eligible for awards. The ethnic distribution of this group is unlikely to different from the group as a whole, and the omission of these consultants from the denominator ratio would not produce any serious bias.

If discrimination is an explanation, then it can arise at two stages: at nomination and at awarding. We have no information on the ethnic composition of those who are nominated or on those who are turned down by the regional committees. However, the fact that the end result is the under-representation of consultants from ethnic minorities, particularly in certain specialties and regions, suggests that something other than sheer excellence is operating at these stages. We have no information on the composition of regional award committees, and there is only one consultant from an ethnic minority who sits on the national advisory committee. If these committees are predominantly white and male they could be open to accusations of bias against women and ethnic minorities.

Distinction awards are an important source of income for consultants: an A + award is worth $£ 52925$ a year, an A award £38 995, and a B award £22 285. A system which appears systematically to exclude a section of the consultant workforce from recognition and reward cannot be defended. We have previously shown that racial discrimination is widespread in the NHS. $^{3-5}$ In the absence of more information on the workings of the distinction award system-at present it is cloaked in secrecy-charges of racial discrimination

Proportion of white consultants obtaining distinction awards compared to non-white consultants by type of award, specialty, and region of employment (1996)

\begin{tabular}{|c|c|c|c|c|c|c|}
\hline & \multicolumn{2}{|c|}{$\begin{array}{l}\text { No of awards to consultants by } \\
\text { ethnic group (\% of all awards) }\end{array}$} & \multicolumn{3}{|c|}{$\begin{array}{l}\text { No of consultants by ethnic group eligible for awards } \\
\text { (\% of consultants) }\end{array}$} & \multirow{2}{*}{$\begin{array}{l}\text { Ratio of proportion of white } \\
\text { to non-white consultants in } \\
\text { receipt of awards ( } 95 \% \\
\text { confidence intervals) } \dagger\end{array}$} \\
\hline & White & Non-white & White & Non-white & Not known & \\
\hline All awards & $2571(95)$ & $143(5)$ & $14713(74)$ & $2722(14)$ & $2342(12)$ & 3.33 (2.82 to 3.92 ) \\
\hline A+ & $213(96)$ & $9(4)$ & & & & 4.38 (2.25 to 8.52$)$ \\
\hline A & $716(97)$ & $22(3)$ & & & & 6.02 (3.95 to 9.18$)$ \\
\hline Anesthetics & $200(97)$ & $7(3)$ & $1999(75)$ & $327(12)$ & $329(13)$ & 4.67 (2.22 to 9.84$)$ \\
\hline Cardiology & $62(98)$ & $1(2)$ & $327(78)$ & $44(11)$ & $47(11)$ & 8.34 (1.19 to 58.67$)$ \\
\hline General medicine & $249(97)$ & $7(3)$ & $246(72)$ & $38(11)$ & $59(17)$ & \\
\hline General surgery & $210(96)$ & $9(4)$ & $921(79)$ & $92(8)$ & $147(13)$ & 2.33 (1.24 to 4.38$)$ \\
\hline Haematology & $64(94)$ & $4(6)$ & $332(74)$ & $51(11)$ & $67(15)$ & 2.46 (0.94 to 6.46$)$ \\
\hline Neurology & $61(98)$ & $1(2)$ & $221(85)$ & $18(7)$ & $21(8)$ & 4.97 (0.73 to 33.78) \\
\hline Obstetrics and gynaecology & $117(95)$ & $6(5)$ & $752(75)$ & $132(13)$ & $119(12)$ & 3.42 (1.54 to 7.61$)$ \\
\hline Ophthalmology & $54(90)$ & $6(10)$ & $408(73)$ & $85(15)$ & $68(12)$ & $1.88(0.83$ to 4.22$)$ \\
\hline ENT & $44(88)$ & $7(12)$ & $304(69)$ & $80(19)$ & $54(12)$ & 1.65 (0.77 to 3.53 ) \\
\hline Paediatrics & $154(96)$ & $7(4)$ & $856(75)$ & $165(14)$ & $129(11)$ & 4.24 (2.03 to 8.88$)$ \\
\hline Radiology & $125(96)$ & $5(4)$ & $1041(72)$ & $218(15)$ & $187(13)$ & 5.24 (2.17 to 12.65$)$ \\
\hline Orthopaedic surgery & $78(97)$ & $2(3)$ & $762(76)$ & $117(12)$ & $124(12)$ & 5.99 (1.49 to 24.04$)$ \\
\hline \multicolumn{7}{|l|}{ NHS region } \\
\hline South and West & $250(97)$ & $8(3)$ & $1772(83)$ & $101(5)$ & $261(12)$ & 1.78 (0.91 to 3.50$)$ \\
\hline North West & $291(93)$ & $23(7)$ & $2108(82)$ & $468(18)$ & $9(0.3)$ & 2.81 (1.86 to 4.24$)$ \\
\hline Wales* & $125(94)$ & $8(6)$ & $807(74)$ & $148(14)$ & $126(12)$ & 2.87 (1.43 to 5.73 ) \\
\hline
\end{tabular}

*Distribution of consultants used in denominator calculated from English data.

†Mantel-Haenszel $\chi^{2}$ of no difference between regions $=272 ; p<0.0001$. 
in the allocation of distinction awards can be also brought against the system.

AE carried out this study while a Harkness Fellow of the Commonwealth Fund of New York. We thank the Department of Health for providing us with the data on the NHS workforce.

Contributors: AE planned the study, carried out the analysis, and wrote the paper and acts as guarantor. HD collected the data from the various reports and prepared them for analysis. SE initiated the idea and participated in writing the paper. Funding: None

Conflict of interest: $\mathrm{AE}$ and $\mathrm{SE}$ are vice presidents of the Medical Practitioners Union, which is opposed to the present system of distinction awards for NHS consultants.

Advisory Committee on Distinction Awards. Report on the 1996 awards round. London: Department of Health, 1997.

2 Hospital Medical Staff: England and Wales. National and regional tables. Leeds: Statistics (Workforce) Branch, National Health Service Executive, 1996
3 Esmail A, Everington S. Racial discrimination against doctors from ethnic minorities. BMJ 1993;306:691-2.

Esmail A, Everington S. Asian doctors still being discriminated against. BMJ 1997;314:1619.

5 Esmail A, Everington S. Complaints may reflect racism. BMJ 1994;308:1374.

\section{Correction}

Comparison of blood or urine testing by patients with newly diagnosed non-insulin dependent diabetes: patient survey after randomised crossover trial

An error occurred in this paper by Pat Miles and colleagues (9 August 1997, pp 348-9). The first sentence of the final paragraph of the subjects, methods, and results section should read: "At 6 months, 42\% (47 [not 63]) opted for urine testing and 48\% (53 [not 72]) for blood testing; 10\% (11 [not 15]) chose both."

\title{
Association between use of a quilt and sudden infant death syndrome: case-control study
}

\author{
Anne-Louise Ponsonby, Terence Dwyer, David Couper, Jennifer Cochrane
}

The relation between an infant's sleeping environment and development of the sudden infant death syndrome depends on the infant's sleep position. ${ }^{1}$ We report how the association between the use of a quilt and the syndrome depends on sleep position.

\section{Subjects, methods, and results}

Between 1 October 1988 and 31 December 1995 in Tasmania 107 infants $<1$ year old died of the sudden infant death syndrome. Of the families affected, 100 $(93 \%)$ participated in this study and were compared directly with 196 age matched controls. Methods are described elsewhere. ${ }^{1}$ A quilt is a coverlet made by stitching two thicknesses of fabric together with a filling (usually synthetic) enclosed between the layers. Conditional multiple logistic regression ${ }^{2}$ was used to evaluate interaction effects; EGRET 0.26.6 software (Cytel Software, Cambridge, MA, USA) provided matched odds ratios with logit-based 95\% confidence intervals.

An adverse effect of quilt use was evident in infants who did not sleep prone but not in infants who slept prone (table). This interaction was not altered by adjustment for sleeping on sheepskin; the interaction between sleeping on sheepskin and sleeping prone; mattress liner; mattress type; use of a quilt under the infant; use of a pillow; infant illness; heating in the bedroom; amount of thermal insulation over the infant; maternal age; or family history of asthma. Adjustment for maternal smoking, breast feeding, or swaddling increased the size of the interaction.

A model was constructed to test whether the interaction was a marker for one of the previously identified modifiers of the prone position, ${ }^{1}$ with indicators for maternal smoking, use of a quilt, swaddling during last sleep, use of a natural fibre mattress, infant illness, and use of bedroom heating during last sleep; the interaction between the last five variables and the prone position was also evaluated. The interaction effect remained $(\mathrm{P}=0.01)$. An adverse effect of the use of a quilt was found among infants who did not sleep prone (adjusted odds ratio $6.16 ; 2.01$ to 18.87 ) but not among those who slept prone. Thus the interaction could not be explained by these factors. The interaction between sleep position and use of a quilt remained for infants and controls who slept in their own cot during the index sleep.

The adverse effect of quilt use among infants who did not sleep prone was greater in infants $\geqslant 12$ weeks old (odds ratio $6.77 ; 1.14$ to 40.21 ) than in younger infants (odds ratio 1.62; 0.27 to 9.59). Adjustment for being found prone reduced the effect of quilt use (adjusted odds ratio $3.16 ; 1.16$ to 8.60 ) suggesting that part of the adverse effect of quilts may occur by allowing infants to roll into the prone position. Among infants who did not sleep prone adjustment for swaddling, maternal smoking postnatally, breast feeding, and type of mattress gave an odds ratio of 5.63 (1.69 to 18.72) for quilt use. Review of the data at the infant's death scene showed that infants found supine with facial obstruction were reported by at least one witness to have had an overlying quilt. The risk of the sudden infant death syndrome for quilt use varied by usual sleep position (common odds ratio test

Relation between use of quilt and the sudden infant death syndrome according to usual sleeping position. Values are odds ratios ( $95 \%$ confidence intervals)

\begin{tabular}{lcc} 
Usual sleep position & $\begin{array}{c}\text { No quilt used during } \\
\text { last sleep }\end{array}$ & $\begin{array}{c}\text { Quilt used during } \\
\text { last sleep }\end{array}$ \\
\hline Supine or on side & 1.00 & $3.81(1.68$ to 8.65$)$ \\
\hline Prone & $9.19(3.24$ to 26.05$)$ & $9.53(3.52$ to 25.81$)$ \\
\hline
\end{tabular}

Menzies Centre for Population Health Research, University of Tasmania, GPO Box 252-23, Hobart, Australia 7001

Anne-Louise

Ponsonby, deputy director of research Terence Dwyer, director David Couper, biostatistician Jennifer Cochrane, research officer Correspondence to: Dr Ponsonby A.L.Ponsonby@ menzies.utas.edu.au

BMJ 1998;316:195-6 